Role of agricultural engineering in environmental and sustainable development

for the valley and delta areas: 1485 - 1498

\title{
EFFECT OF MIXING CEMENT WITH RICE STRAW TO USING AS BUILDING BRICKS
}

\section{Tayel S.A. 2. Khairy M.F.A. 3. EL-Soaly I.S. 4. Moussa A.M.}

\section{ABSTRACT}

The purpose of this research was to investigate the effects of mixing cement with rice straw on brick making. Two particles size of rice straw were used namely small rice straw chops and large chops. Three formation pressures were used (by handle, 1.3 and 2.5 MPa). Four different ratios of cement were used $(35,45,60$, and $75 \%)$. The quality of the bricks was evaluated through the measurements of bulk density, thermal conductivity, water absorption percentage, expansion percentage and compressive strength. The obtained data showed that increasing of cement percentage lead to increase bulk density for both small and large rice straw chops, and increasing formation pressure lead to increase bulk density for both small and large rice straw chops, and the values of bulk density were higher at small chops than large chops. The minimum value of bulk density was $0.29 \mathrm{~g} / \mathrm{cm}^{3}$ at pressing by handle and mixture percentage of $35 \%$ for large chops, the maximum value was $1.242 \mathrm{~g} / \mathrm{cm}^{3}$ at $2.5 \mathrm{MPa}$ and mixture percentage of $75 \%$ for large chops. The minimum value of thermal conductivity was $0.062 \mathrm{~W} / \mathrm{m} .{ }^{\circ} \mathrm{c}$ at pressing by handle and mixture percentage of $35 \%$ for small chops, the maximum value was $0.204 \mathrm{~W} / \mathrm{m} .{ }^{\circ} \mathrm{c}$ at $2.5 \mathrm{MPa}$ and mixture percentage of $75 \%$ for small chops. Water absorption decreased with increasing of cement percentage for both small and large rice straw chops, and increasing formation pressure lead to decrease water absorption for both small and large rice straw chops, and water absorption percentage increases with the increase of absorption time " $\mathrm{T}$ " (h). The values of water absorption percentage were higher at large chops than small chops. The minimum value of water absorption percentage was $32.06 \%$ after $1 \mathrm{~h}$ at $2.5 \mathrm{MPa}$ and mixture percentage of $75 \%$ for small chops. The maximum value of water absorption percentage was $195.13 \%$ after $3 \mathrm{~h}$ at pressing by handle and mixing ratio of $35 \%$ for small chops.

1-Prof. of Ag. Eng., 2- Prof. and head of Ag. Eng., 3- Assoc. Prof. of Ag. Eng., 4- Assist. Lect. of Ag. Eng.,

All authors are of Ag. Eng. Dept., Fac.of Ag., Al-Azhar Univ. Cairo. 
Expansion percentage decreased with increasing of cement percentage for both small and large rice straw chops, and increasing formation pressure lead to increase expansion percentage for both small and large rice straw chops. The values of expansion percentage were higher at large chops than small chops. The minimum value of expansion percentage was $0.70 \%$ at pressing by handle and mixture percentage of $75 \%$ for small chops; the maximum value was $44.20 \%$ at $2.5 \mathrm{MPa}$ and mixture percentage of $35 \%$ for large chops. Compressive strength increases with increasing of cement percentage for both small and large rice straw chops. The values of compressive strength were higher at small chops than large chops. The minimum value was 1.75 at pressing by handle and mixture percentage of $35 \%$ for small chops, the maximum value of compressive strength was $182.15 \mathrm{~kg} / \mathrm{cm}^{2}$ at $2.5 \mathrm{MPa}$ and mixture percentage of $75 \%$ for small chops.

\section{INTRODUCTION}

The problem of increasing field residues and how to dispose are the biggest problems of agricultural biomass wastes in Egypt. The traditional way for disposing is by burning which not only caused pollution to environment, but also loosing an economic value of these residues, if it were used to produce useful products. This problem became greater nowadays which introduce black clouds covered Cairo's Sky and surrounding region during rice harvesting time. The straw burning process may be considered as the main reason for this black clouds appearance especially after developing a rural kitchen in villages.(El-

\section{Bessoumy, 2005)}

Recently, there is a high level of interest towards agricultural residues utilization in useful ways that will help keeping healthy and friendly environment. There are great efforts towards recycling agricultural residues.

There are different means to solve or diminish this problem; as:

1. Using these residues for animal feedings or bedding material for farm animals.

2. Using these residues as organic fertilizer.

3. Utilizing these residues in recycling industry as in making paper, pressed wood, packaging and building materials. 
4. Utilizing these residues in soil less culture.

5. Utilizing these residues in biomass fuel.

6. Utilizing these residues in biogas production. (Awady 2002) F.A.O (2005) mentioned that the total annual Egyptian crop residues are about $30 \mathrm{Tg}$ as shown in Table.1.

Table 2.1: The Egyptian crop residues by - products: (FAO, 2005).

\begin{tabular}{|c|c|}
\hline Amount of & Mg / year \\
\hline Wheat straw & 6280000 \\
\hline Barley stalks & 896000 \\
\hline Beans stalks & 400000 \\
\hline Rice straw & 2800000 \\
\hline Other residues & 375000 \\
\hline Grain sweet stalks & 6000000 \\
\hline Grain sorghum stalks & 1050000 \\
\hline Cotton stalks & 1400000 \\
\hline Corn core & 2200000 \\
\hline Sugarcane residues & 2146500 \\
\hline Sugar beet residues & 1224000 \\
\hline Vegetable residues & 3204000 \\
\hline Fruit residues & 1853500 \\
\hline Total & 29829000 \\
\hline
\end{tabular}

Toepfer (2002) said that the pollution was caused by the burning of agricultural wastes and fossil fuels, and inefficient cooker emissions from burning.

Nouno (2003) mentioned that air quality is one of Egypt's more pressing environmental problems, and the smoke from smoldering rice straw pits is one of the major causes of the seasonal, thick, brown smog that hangs over the city scope. The disposal option now accounts for an estimated $90 \%$ of the straw, with the remainder used in fodder or incorporated into the soil.

Zein-Eldin and Sadaka (2000) used adhesive material (cement) with some wastes such as sawdust, rice hall, rice hay and beans stalks to making mixture and their results indicated that the rice hall bricks have the highest general suitable while beans-stalk bricks had the lowest 
values. They also revealed that all types of bricks are accepted as carrying bricks except beans-stalk brick with mixing ratios of 8: 1 and 12: 1 cement: waste and the mixing ratio less than $8: 1$ corresponding to the other three types of waste materials should not be used as carrying bricks for more safety.

Savastano et al. (2000) studied the effect or reinforced cement - based composites by Brazilian waste fibers. Fiber reinforced cement - based composites were prepared using Kraft pulps from sisal and banana wastes and from Eucalyptus grand's pulp mill residues. Mechanical testing showed that optimum performance of the various waste fiber reinforced composites was obtained at a fiber content of around $12 \%$ by mass, with flexural strength values of about $20 \mathrm{MPa}\left(204 \mathrm{~kg} / \mathrm{cm}^{2}\right)$. Nouno (2003) mentioned that the process of making the materials is sufficiently simple to put it within reach of local communities. Essentially, residual crops are mixed with a binding (matrix) material in a $70 / 30$ ratio. The binding material is basically limestone, which is readily available in Egypt. A tiny amount of fiber glass is added, which represents $0.05 \%$ of the mix. Some equipment is needed, but it is inexpensive.

John (1999) found that the most apparent and widely used example of inorganic- bonded composites is cement. Portland cement, when combined with water, immediately reacts in a process called hydration to eventually solidify into a solid stone like mass. Successfully marketed Portland cement-bonded composites consist of both low-density products made with excelsior or coir and high-density products made with particles and fibers.

Therefore, the main aim of this research was to investigate and evaluate technically the effects of mixing cement with rice straw on brick characteristics. The characteristics of these bricks were evaluated using criteria of bulk density, thermal conductivity, water absorption percentage, expansion percentage and compressive strength.

\section{MATERIALS AND METHODS}

The experiments were carried out at the workshop of Agricultural Engineering Department, Faculty of Agriculture, Al-Azhar University. Cement was used with two cutting sizes of rice straw with adding amount 
of water. Four different mixing ratios were chosen to binding material in mixture. These mass ratios were 35, 45, 60 and 75\%. Three levels of formation pressure were used namely, by handle, 1.3 and $2.5 \mathrm{MPa}$. Samples were manually mixed to dry in the air for 21 days. Two particles sizes of rice straw were used in this study, large and small chops. These chops were obtained by using a grinding forage machine. Cylindrical specimens were produced to measure thermal conductivity with inner diameter of $105.4 \mathrm{~mm}$; outer diameter of $110 \mathrm{~mm}$, and length of 210 $\mathrm{mm}$.. Rectangular specimens were produced for other measurements. The pressing mold dimensions were $25 \times 12 \times 10 \mathrm{~cm}$.

\section{- Pressing apparatus:-}

The pressing apparatus was used to produce the samples at different formation pressures, PM (PMa). The technical specification of the hydraulic pressing are (according to manufacturing catalogue): Max Capacity $20 \mathrm{Mg}$; Gauge 0-60 MPa; Resolution of $2 \mathrm{MPa}$ Made by SICMI sa, Trecasali (Parma), Italy (1996).

\section{-Thermal conductivity apparatus:}

A thermal conductivity apparatus was used "K"(W/ $\left.\mathrm{m} .{ }^{\circ} \mathrm{c}\right)$ of building material samples. An apparatus was developed according to Lees' method (Noakes.,1953). The apparatus was constructed at the workshop of Ag. Eng. Dept., Faculty of Ag. AL-Azhar Un. (EL-Bessoumy,2005).

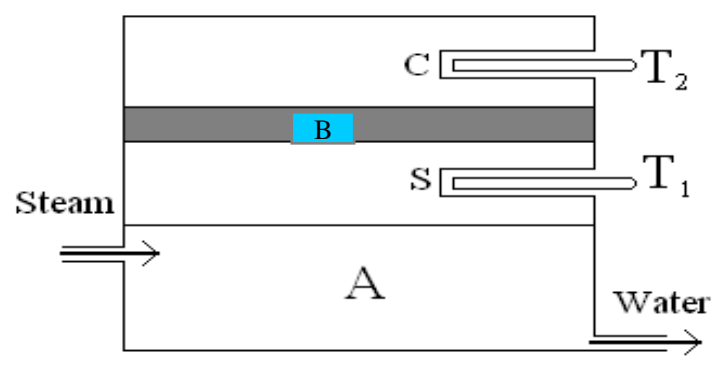

Fig. (1): A schematic diagram for steam unit and sample of thermal conductivity apparatus (C, S) Brass disks, (B) Sample, $\left(\mathrm{T}_{1}, \mathrm{~T}_{2}\right)$ Thermometers. - Moisture content "MC" (\%):

Water was added by different quantities based on type of mixing ratio, and measuring moisture content $(\%)$ for mixtures before and after forming pressure. 


\section{Measurements:}

\section{1- Bulk density "B.D":}

calculated by equation:

(B.D.) $=\mathrm{M} / \mathrm{V}$

where; M: mass of sample, $\mathrm{V}$ : volume of specimens.

\section{2-Thermal conductivity " $k$ ":}

The thermal conductivity " $k$ " for sample was calculated from the following equation:

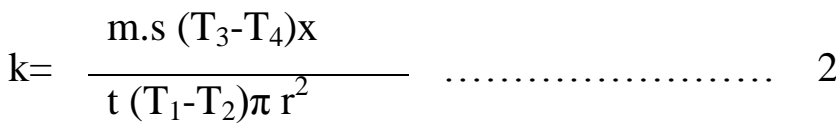

$$
\begin{aligned}
& =\frac{32492\left(\mathrm{~T}_{3}-\mathrm{T}_{4}\right) \mathrm{x}}{\mathrm{t}\left(\mathrm{T}_{1}-\mathrm{T}_{2}\right)} \ldots \ldots \ldots \ldots \ldots \ldots \ldots \ldots \ldots \ldots \ldots
\end{aligned}
$$

Where:

$\mathrm{k}$ : $\quad$ Thermal conductivity for sample, $\mathrm{W} / \mathrm{m} .{ }^{\circ} \mathrm{C}$.,

$\mathrm{m}$ : $\quad$ Mass of brass disk (C) of $0.74 \mathrm{~kg}$.,

$\mathrm{r}$ : $\quad$ The radius of sample, $\mathrm{m}$.,

$\mathrm{t}$ : $\quad$ Time, s.,

$\mathrm{S}: \quad$ Specific heat for brass, $380 \mathrm{~J} / \mathrm{kg} .{ }^{\circ} \mathrm{C}$.,

$\mathrm{x}$ : $\quad$ Thickness of sample, $\mathrm{m}$,

$\mathrm{T}_{3}$ : $\quad$ Temperature of brass disk (C) above $\mathrm{T}_{2},{ }^{\circ} \mathrm{C}$. and

$\mathrm{T}_{4}$ : $\quad$ Temperature of brass disk $(\mathrm{C})$ below $\mathrm{T}_{2}$ as $\mathrm{T}_{3}$ was above it, ${ }^{\circ} \mathrm{C}$.

\section{3- Expansion percentage:}

All specimens in the present study expanded, this is because adding the rice straw. Thickness of specimens was measured when they were wetted and after dried it, and expansion percentage was calculated as follows:

Expansion "E",\% $\frac{\text { Dry thickness - Wet thickness }}{\text { Wet thickness }} \times 100 \quad=\ldots \ldots \ldots \ldots .4$

\section{4- Compressive strength:}

The compression test was carried out by placing the specimen (after measure its dimensions) between two parallel plates, a continuous load was at a constant cross head rate until failure. The compressive strength $\sigma$ was calculated as follows: 


$$
\sigma=\frac{\mathrm{F}}{\mathrm{A}} \quad, \quad \mathrm{kN} / \mathrm{m}^{2} \quad \ldots \ldots \ldots \ldots \ldots
$$

Where:

F : Force, kN. and

A : $\quad$ Specimen surface area, $\mathrm{m}^{2}$.

\section{5- Water absorption:}

The water absorption test was carried out by using cylindrical specimens, the initial mass for specimen was recorded, each specimen was placed on a narrow wiry mesh and immersed in fresh, clean water at $293-295^{\circ} \mathrm{K}$ $\left(20-22^{\circ} \mathrm{C}\right)$ for duration of $1,2,3$ and $4(\mathrm{~h})$ at the end of each period a sample and a narrow wiry mesh were withdrawn from water and the excess water was strained, then was weighed again, every specimen was soaked again to another period of 1 hour the same measurements were executed and recorded and so on until 4 hours were last. In the end of these fore hours the water absorption percentage (Wa) was calculated as follows:

$$
\text { "Wa" }=\frac{\mathrm{M}_{\mathrm{w}}-\mathrm{M}_{\mathrm{d}}}{\mathrm{M}_{\mathrm{d}}} \times 100, \% \ldots \ldots \ldots \ldots 6
$$

Where:

$\mathrm{M}_{\mathrm{W}} \quad$ : Mass of wet sample (g). and

$\mathrm{M}_{\mathrm{d}} \quad$ : Initial mass of specimen (g).

\section{Preparation of test specimens:}

Two shapes from specimens were prepared, rectangular and cylindrical. Cylindrical specimens were produced to measure thermal conductivity and water absorption. Rectangular specimens were produced to the other measurements (bulk density, expansion percentage and compressive strength). Specimens were manually mixed using the proposed mixing ratios. The mortar was made by adding water to straw and then mixed with cement. The molds were placed on a wooden surface that covered with a thin layer of sand to prevent sticking. The molds were filled in segments, and the mix was compacted by hand as much as possible to prevent air voids. Manufacturing batches were segmented to two levels pressure and one pressing by handle of 1.3 and $2.5 \mathrm{MPa}$. The first level (pressing by handle) was placed immediately on a wooden surface. Other 
levels (1.3 and 2.5 $\mathrm{MPa}$ ) were placed under hydraulic piston. The specimens were dried in air for about 21 day.

\section{1- Bulk density:}

\section{RESULTS AND DESCUSSION}

Fig. 2 show the relationship between bulk density and four cement percentage for bricks at the three different pressures for small and large rice straw chops.

Results indicated that bulk density increases with increasing cement percentage and increases with increasing formation pressure for both small and large chops. These results were expected because the pressures affected on the volume of specimens. The values of bulk density were higher at small chops than large chops, this is may be due to the small shops can compact easy more than large chops with cement and have lowered porous. The minimum value of bulk density was $0.29 \mathrm{~g} / \mathrm{cm}^{3}$ at pressing by handle and mixture percentage of $35 \%$ for large chops, the maximum value was $1.242 \mathrm{~g} / \mathrm{cm}^{3}$ at $2.5 \mathrm{MPa}$ and mixture percentage of $75 \%$ for large chops. These values of bulk density lead to classify these bricks according to interbuild specification encyclopedia (2003) as a medium in class weight. The standard bulk density of cement- bricks were of 1.2 to $1.5 \mathrm{~g} / \mathrm{cm}^{3}$ and sand- bricks were of 0.60 to $0.65 \mathrm{~g} / \mathrm{cm}^{3}$. These results indicate that the brick made using the rice straw, considered in this study and its mixing ratios, are in the acceptable range of weights and these could be considered as an advantage.

\section{2- Thermal conductivity:}

Fig. 3 illustrate the relationship between thermal conductivity "k" and four cement percentage for bricks at the three different pressures for small and large rice straw chops. The data indicate that the thermal conductivity increases with the increase of cement percentage and increases with increasing formation pressure for both small and large chops. The values of thermal conductivity were lower (high insulation) at large chops than small chops in the overall adhesive materials. This is may be due to that the large chops have wide porous than small chops. 
Large chops

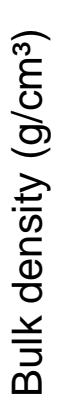

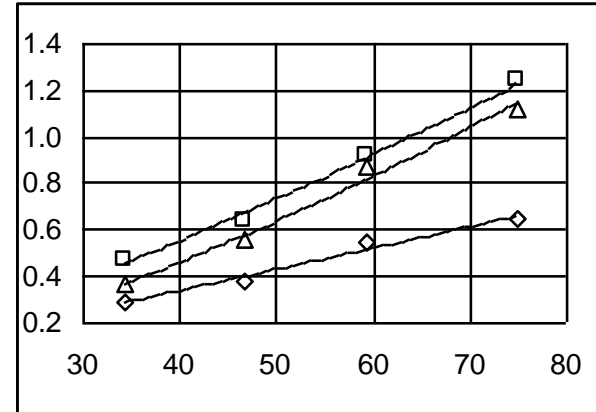

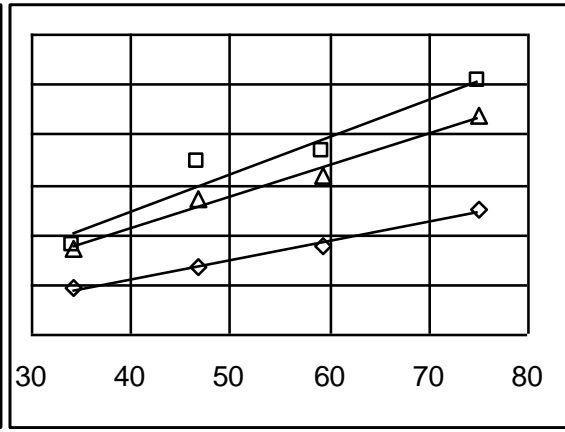

Cement percentage, $\%$

Small chops

Fig.2: Relation between bulk density $\left(\mathrm{g} / \mathrm{cm}^{3}\right)$ and cement ratios $(\%)$ in brick at different formation pressure ( $\mathrm{MPa}$ ) for small and large rice straw chops.

Large chops

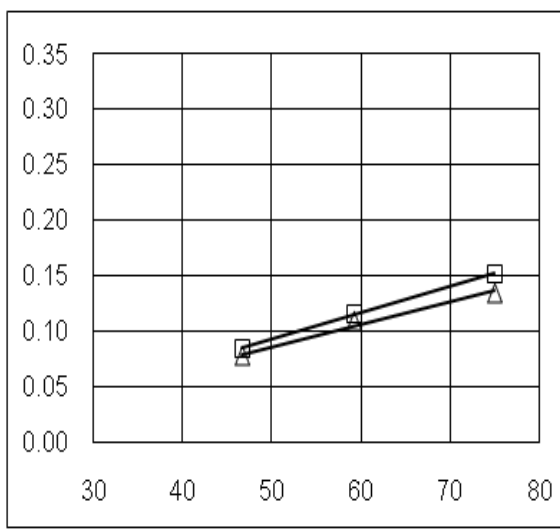

Small chops

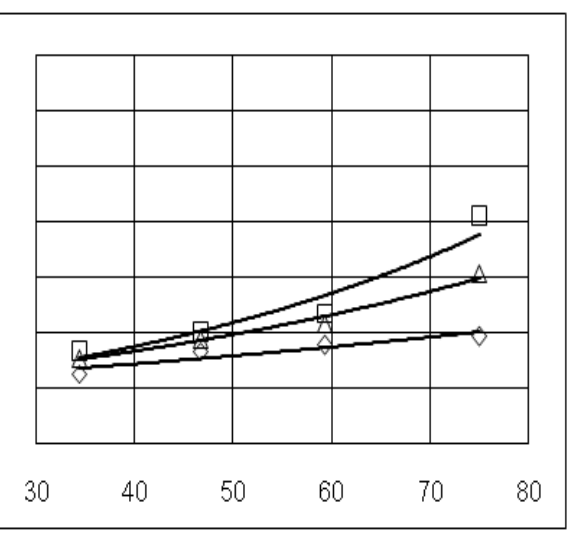

Cement percentage, $\%$

Fig.3: Relation between thermal conductivity "k" $\left(\mathrm{W} / \mathrm{m}^{\circ} \mathrm{c}\right)$ and cement ratios $(\%)$ in brick at different formation pressure (MPa) for small and large rice straw chops.

The minimum value of thermal conductivity was $0.062 \mathrm{~W} / \mathrm{m} .{ }^{\circ} \mathrm{c}$ at pressing by handle and mixture percentage of $35 \%$ for small chops, the maximum value was $0.204 \mathrm{~W} / \mathrm{m} .{ }^{\circ} \mathrm{c}$ at $2.5 \mathrm{MPa}$ and mixture percentage of $75 \%$ for small chops. 
These results lead to these bricks are good heat insulation compared to types other bricks, for example sand-bricks are insulation and its thermal conductivity of 0.27 to $0.34 \mathrm{~W} / \mathrm{m}^{\circ} \mathrm{c}$ interbuild specification encyclopedia (2003).

\section{3- Expansion percentage:}

Fig. 4 show the relationship between expansion percentage and four cement percentage for bricks at the three different pressures for small and large rice straw chops. The obtained data showed that the expansion percentage decreases with increasing binding material percentage for both small and large chops and increases with the increasing formation pressure for both small and large chops. This is may be due to rice straw have high elasticity with pressure. The values of expansion percentage were higher at large chops than small chops. The minimum value of expansion percentage was $0.70 \%$ at pressing by handle and mixture percentage of $75 \%$ for small chops; the maximum value was $44.20 \%$ at 2.5 $\mathrm{MPa}$ and mixture percentage of $35 \%$ for large chops.

Large chops

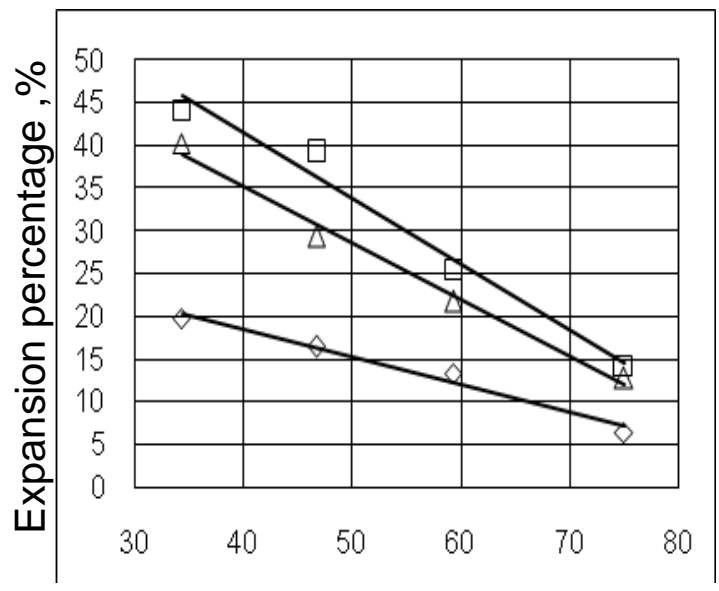

Small chops

\section{Cement percentage, $\%$}

Fig.4: Relation between expansion percentage (\%) and cement ratios(\%) in brick at different formation pressure (MPa) for small and large rice straw chops.

\section{4- Compressive strength:}

Fig. 5 show the relationship between compressive strength " $\sigma$ " and four cement percentage for bricks at the three different pressures for small 
and large rice straw chops. The results indicated that increasing binding material percentage increases compressive strength significantly and increasing formation pressure increases compressive strength significantly for both small and large chops. This is due to the heat generated from the pressure increased the effect of binding materials. The values of compressive strength were higher at small chops than large chops. This is may be due to the large chops have wide porous than small chops. The minimum value was 1.75 at pressing by handle and mixture percentage of $35 \%$ for small chops, the maximum value of compressive strength was $182.15 \mathrm{~kg} / \mathrm{cm}^{2}$ at $2.5 \mathrm{MPa}$ and mixture percentage of $75 \%$ for small chops.

\section{5- Water absorption:}

Fig. 6 illustrate the relationship between water absorption percentage and four cement percentage for bricks at the three different pressures for small and large rice straw chops. Results revealed that increasing amount of cement decreases water absorption significantly and decrease with increasing formation pressure for both small and large chops. The data indicated that the water absorption percentage increases with the increase of absorption time "T". The values of water absorption percentage were higher at large chops than small chops. This is may be due to the large chops have wide porous than small chops in mixture. The minimum value of water absorption percentage was $32.06 \%$ after $1 \mathrm{~h}$ at $2.5 \mathrm{MPa}$ and mixture percentage of $75 \%$ for small chops. The maximum value of water absorption percentage was $195.13 \%$ after $3 \mathrm{~h}$ at pressing by handle and mixing ratio of $35 \%$ for small chops.
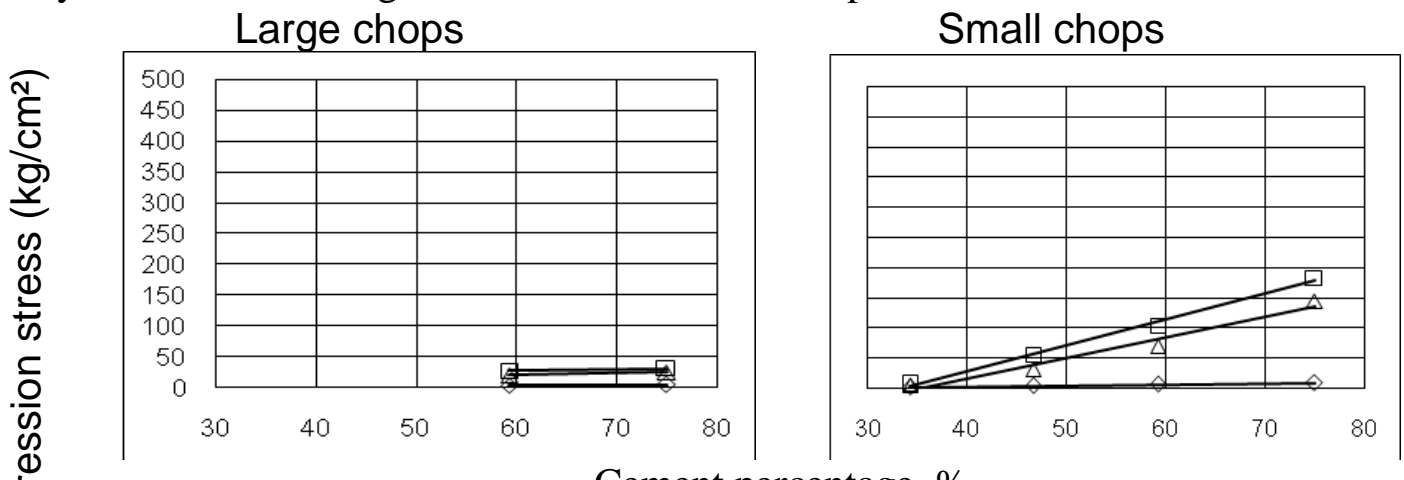

Cement percentage, $\%$

Fig.5: Relation between compression stress $\left(\mathrm{kg} / \mathrm{cm}^{2}\right)$ and cement ratios $(\%)$ in brick at different formation pressure $(\mathrm{MPa})$ for small and large rice straw chops. 
Large chops
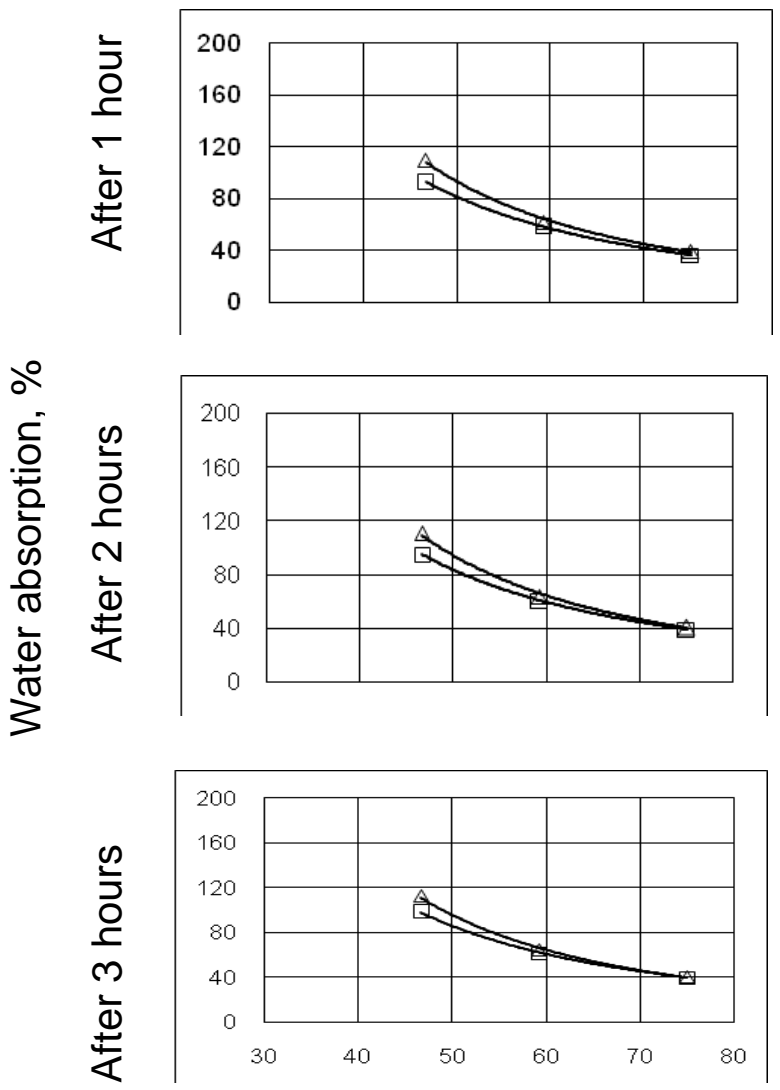

Small chops
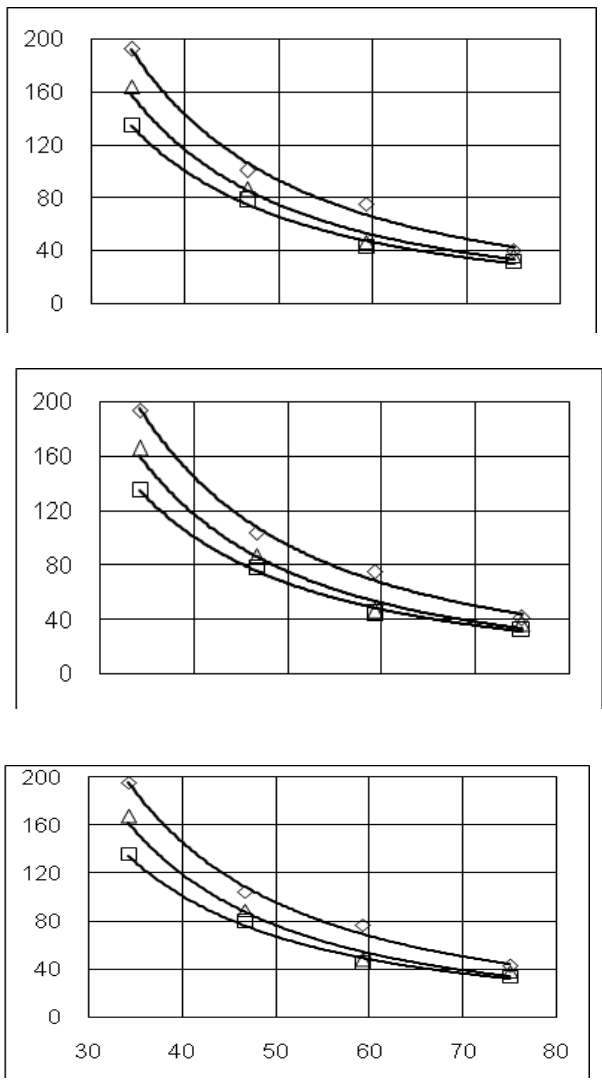

Fig.6 : Relation between water absorption (\%) and cement ratios(\%) in brick at different formation pressure (MPa) for small and large rice straw chops.

\section{REFERENCES}

Awady, M. N. (2002). Seminar on Agricultural Engineering role in utilization from Agricultural wastes and keeping environment. 10th Conference of Misr Society, Agr.Eng. Introduction (in Arabic)

El-Bessoumy, R.R. (2005). Effect of using agricultural residues in building materials characteristics. M.Sc. Thesis. Ag. Eng. Dept, Faculty of Agriculture, Al-Azhar University, 41,43,47,48.

(FAO) Food and Agriculture Organization of the United Nation (2005). Quarterly bulletin of statistics, New York. 
John, A. (1999). Wood -based Composites and Panel Products. From, Forest Product Laboratory. Wood handbook - wood as an engineering material. Gen. Tech. Rep. FPL-GTR- 113. Madison, Wl: U.S. Department of Agriclture, Forest Service, Forest Product Laboratory. 463p.

Nouno, S. (2003). A local professor wants to turn Cairo's burning rice fields into building panels. http://www. businesstodayegypt. com / issues / 0209/ 3E09/ 02093 E09p.asp.

Savastano, H., P.G. Warden and R.S.P. Coutts (2000). Brazilian waste fibers as reinforcement for cement -based composites. Cement and Concrete Composites, (22): 379-384.

Toepfer, K.(2002). Posted on 08/09/2002 1:56:56 PM PDT by Cogitator, LONDON (AFP).

Zein Eldin, A.M. and S.S. Sadaka (2000). Cement-Agro waste bricks strength and its technical assessment. Misr J. Ag. Eng., 17 (2): 266285.

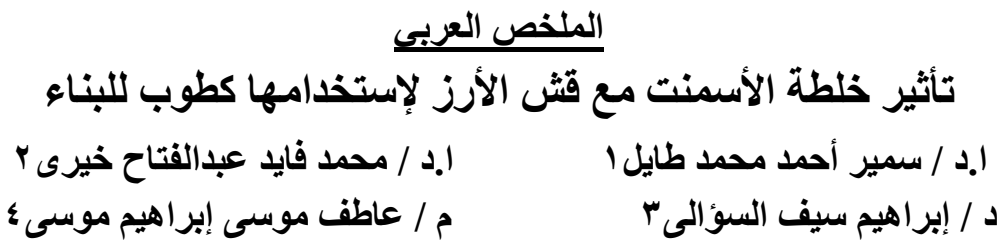

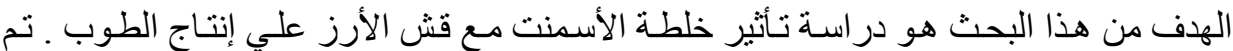

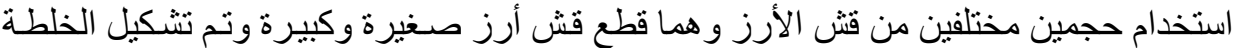

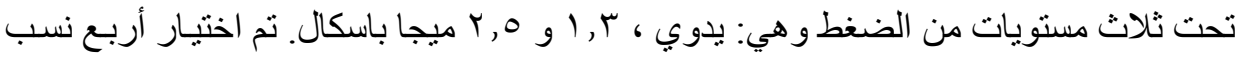

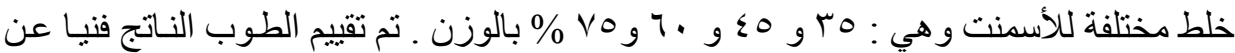

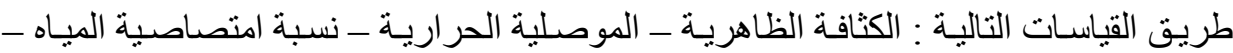

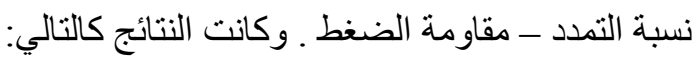

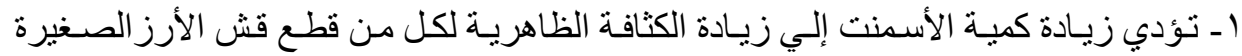

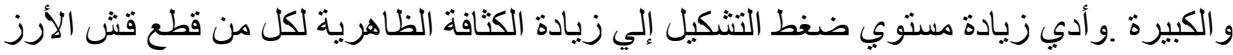
الصغيرة والكبيرة .وكانت قيم الكثافة الظاهرية للقطع الصغيرة أعلي منها في القطع الكبيرة.

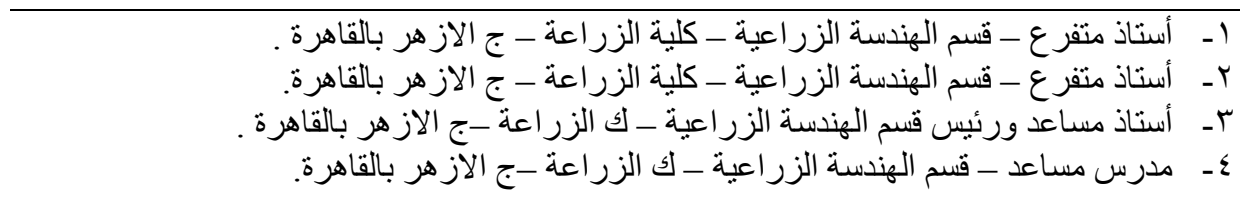




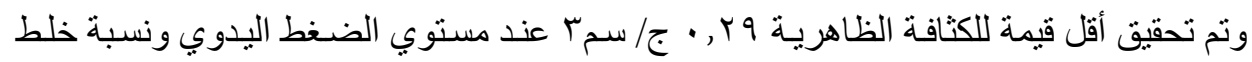

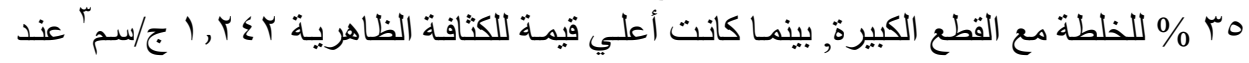

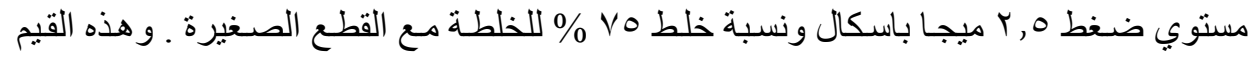

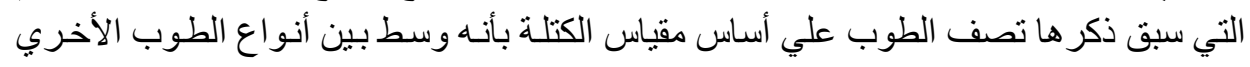

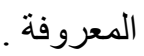
rـ تـؤدي زيـادة كميـة الأسـنت فـى الخلطـة إلـي زيـادة الموصـلية الحر اريـة ( إنخفـاض العـزل

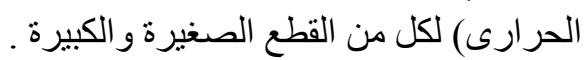

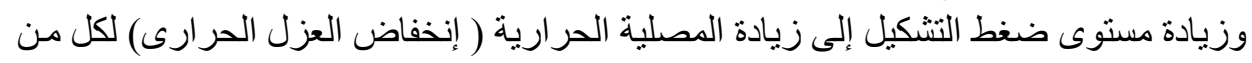
قطع قش الأرز الصغيرة و الكبيرة.

و قيم الموصلية الحر ارية للقطع الصغيرة أعلى منها فى القطع الكبيرة لكل الخلطات المختلفة.

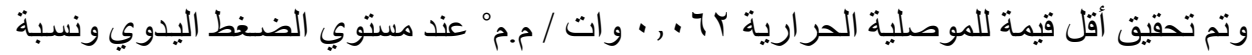

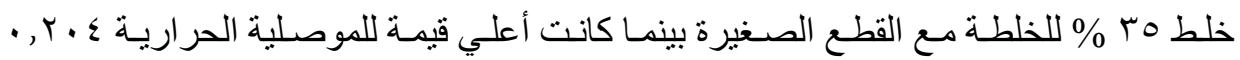

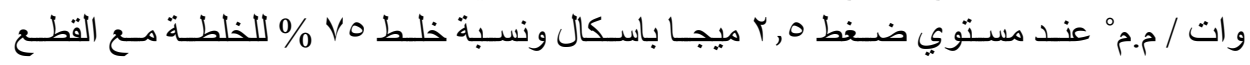
الصغيرة. و هذه النتائج السابقة تصنف هذا الطوب بأنه عازل جيد للتوصيل الحراري .

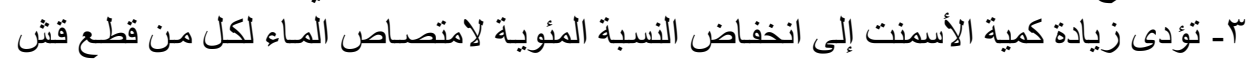

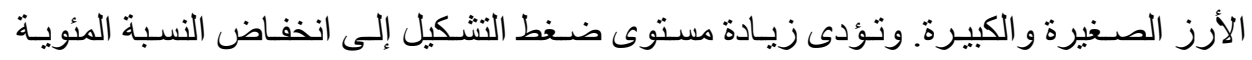

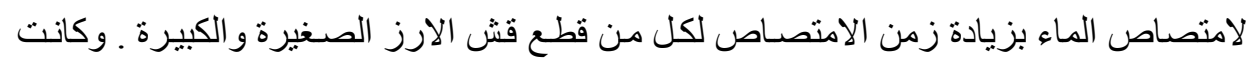

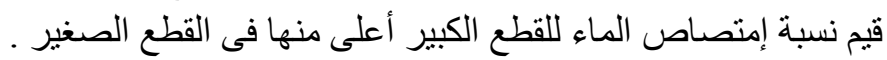

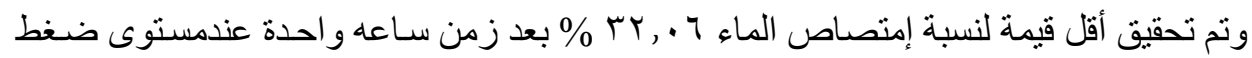

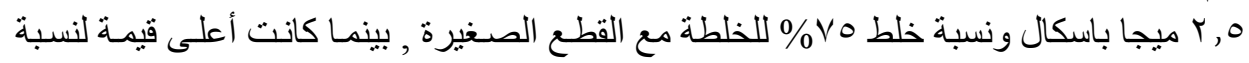

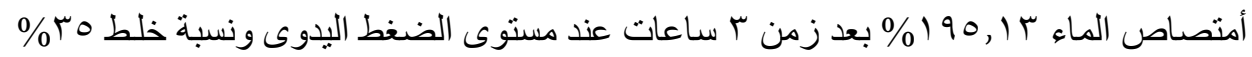
للخلطه مع القطع الصغيره. ع ـ تؤدى زيادة كمية الاسمنت إلى انخفاض النسبة المئويـة للتمدد لكل قطع قش الارز الصـيرة الصغيرة

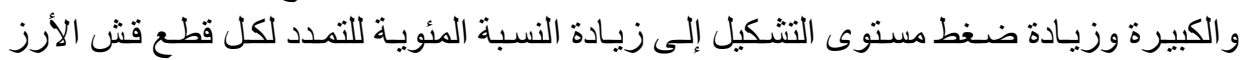

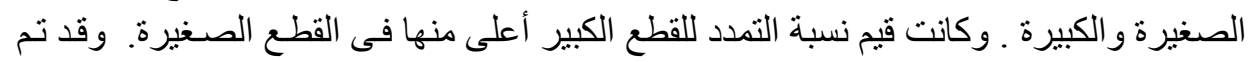

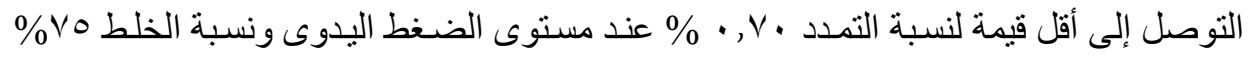

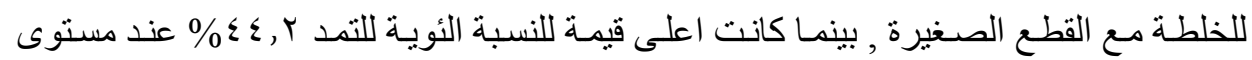

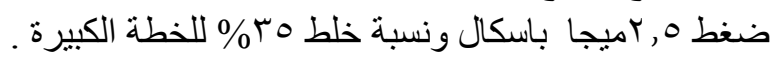

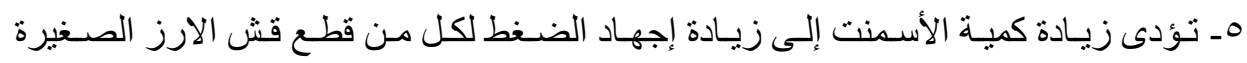

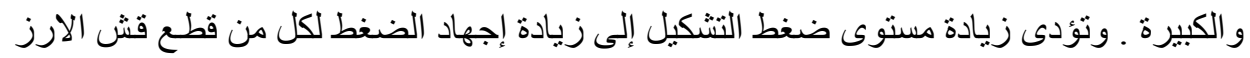
الصغيرة و الكبيرة وقد تم تحقيق قيم إجهاد الضغط للقطع الصغيرة و وأعلى منها فيى القطع الكبيرة

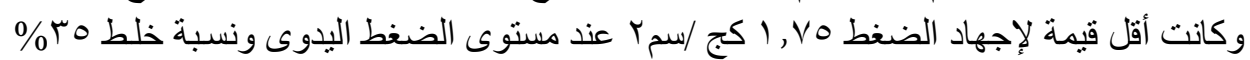

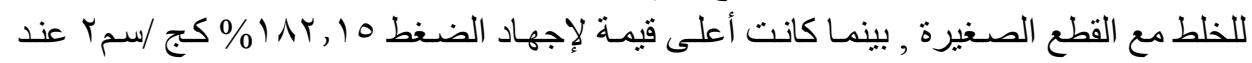

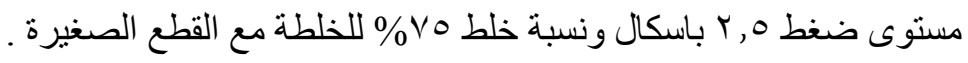

